\title{
Uncovering common pathogenic transcriptional dysregulations in Silver-Russell syndrome
}

\author{
Florian Bohne ${ }^{1 *}$, Ursula Martiné ${ }^{1}$, Matthias Begemann², Thomas Eggermann², Thorsten Enklaar', Dirk Prawitt ${ }^{1}$ \\ From 50th Workshop for Pediatric Research \\ Gottingen, Germany. 20-21 March 2014
}

Silver-Russell syndrome (SRS) is a rare developmental disorder, presenting with marked intrauterine and postnatal growth retardation. The heterogeneous associated molecular defects in approximately $40 \%$ of SRS patients are due to epigenetic changes in the imprinting control region 1 (ICR1) that regulates the monoallelic expression of IGF2 and H19 in cis. Nevertheless a significant number of SRS patients have epigenetic alterations in other imprinted regions instead, like in cases with maternal uniparental disomy for chromosome 7 (upd(7) mat). Using primary fibroblasts from SRS patients with upd(7)mat and a unique case with upd(11)mat, we can show dysregulation of imprinted genes not located on the chromosomes 7 or 11 respectively, but on other chromosomes, suggesting a functional interaction between imprinted genes throughout the genome. $4 \mathrm{C}$ analyses for the ICR1 have shown that this interaction is unlikely to be based on chromatin interactions, but rather due to effects of the gene products themselves. The most likely transfactors mediating the transcriptional regulation of other imprinted genes are long noncoding RNAs. To determine which of these function as transfactors for the transcriptional regulation of other imprinted genes, we performed knock-down assays and monitored the transcriptional consequences on other imprinted genes. Our preliminary analyses also show, that common dysregulation patterns for imprinted genes throughout the genome can be described in SRS patients with different epigenetic alterations, suggesting that these patterns are associated with the clinical phenotype.

Funded by BMBF 01GM1114D.

${ }^{1}$ Center for Pediatrics and Adolescent Medicine, University Medical Center, Mainz, Germany

Full list of author information is available at the end of the article
Authors' details

'Center for Pediatrics and Adolescent Medicine, University Medical Center, Mainz, Germany. ${ }^{2}$ Institute of Human Genetics University Hospital, Aachen, Germany.

Published: 11 September 2014

doi:10.1186/2194-7791-1-S1-A13

Cite this article as: Bohne et al: Uncovering common pathogenic transcriptional dysregulations in Silver-Russell syndrome. Molecular and Cellular Pediatrics 2014 1(Suppl 1):A13.

\section{SpringerOpen ${ }^{\odot}$}

(C) 2014 Bohne et al; licensee Springer This is an Open Access article distributed under the terms of the Creative Commons Attribution License (http://creativecommons.org/licenses/by/2.0), which permits unrestricted use, distribution, and reproduction in any medium, provided the original work is properly cited.
Submit your manuscript to a SpringerOpen ${ }^{\circ}$ journal and benefit from:

- Convenient online submission

- Rigorous peer review

- Immediate publication on acceptance

- Open access: articles freely available online

- High visibility within the field

- Retaining the copyright to your article

Submit your next manuscript at $>$ springeropen.com 